\title{
THE MAKING OF FOREIGN POLICY IN CHINA
}

\author{
by A. Doak Barnett
}

"In attempting to understand policy-making in any country, it is essential to ask certain basic questions. At the top of the political system, what individuals, groups, and institutions play key roles in decision making, and what are their respective roles and relationships? Where does their

information and counsel come from? At operational levels, what mechanisms exist to coordinate the major institutions involved in the conduct of foreign policy? How influential are experts and specialists, and through what channels are their opinions voiced?"

"Until recently, the outside world had little information with which to answer these questions, or even to make informal guesses. Foreign policy making in China appeared to take place in a 'black box'. One could see what policies emerged from the box, but not what went on inside it. Now it is possible to provide partial answers to such questions."

\section{Extract from THE MAKING OF FOREIGN POLICY IN CHINA}

A. Doak Barnett provides the first serious analysis of the process by which China's foreign policy is made, drawing on his own primary research. He describes a major shift in top-level decision-making and the system of analysis on which decisions are based.

\section{I.B.TAURIS \& $\mathrm{C}^{\circ} \mathbf{I}^{\mathrm{td}}$}

\section{Publishers}

3 Henrietta Street, Covent Garden, London WC2E 8PW Tel: 01-836 5814 Telex: 261507/3166 Tauris 


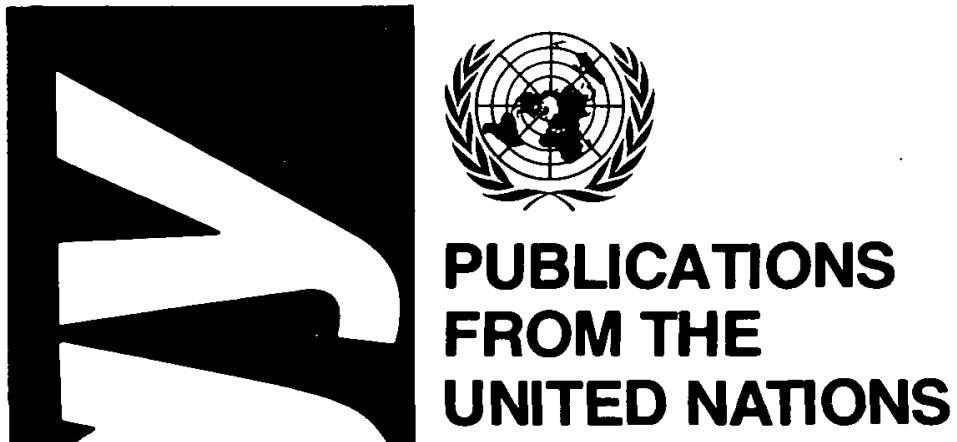

ENERGY STATISTICS YEARBOOK

The Energy Statistics Yearbook (formerly Yearbook of World Energy Statistics) is a comprehensive collection of international energy statistics prepared by the

Statistical Office of the United Nations. It is the twenty-sixth in a series of annual compilations which commenced under the title World Energy Supplies in Selected Years, 1929-1950.

E/F.84.XVII.4

$\$ 60.00$

MAIN FEATURES AND TRENDS IN PETROLEUM AND MINING AGREEMENTS

Prepared by United Nations Centre on Transnational Corporations

$$
\text { E.83.II.A.9 }
$$

ENERGY IN THE EIGHTIES

Highlights of the Meeting of the Ad Hoc Group of Energy and Petroleum Experts E.83.II.A.16

A GUIDE TO OCEAN THERMAL ENERGY CONVERSION FOR DEVELOPING COUNTRIES E.83.II.A.21

ENERGY TRANSITION IN THE ECE REGION.

E.83.II.E.21

$\$ 16.50$

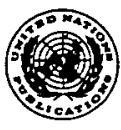

For further titles please request a free copy of our Catalogue of International Publications

UNITED NATIONS PUBLICATIONS

Room DC2-853, New York, N.Y. 10017

Palais des Nations, 1211 Geneva 10, Switzerland 


\section{CAMBRIDGE Trade and Civilisation in the Indian Ocean}

An Economic History from the Rise of Islam to 1750

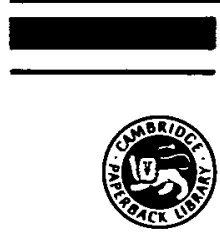

K. N. CHAUDHURI

This book examines the long chain of oceanic trade which stretched from the South China Sea to the eastern Mediterranean prior to the middle of the eighteenth century. It points out for the first time the unique and limiting features of Asian commercial capitalism, and shows how the contribution of Asian merchants was valued universally in reality if not legally and formally.

Hard covers $\$ 25.00$ net Paperback \&8.95 net

\section{The Sole Spokesman}

Jinnah, the Muslim League and the Demand for Pakistan AYESHA JALAL

An examination of the events of the seven years from 1940, when the All-India Muslim League first voiced its demand for an independent state of Pakistan, to the partition of India in 1947. Dr Jalal focuses in particular on the role of Mohammad Ali Jinnah, the charismatic head of the Muslim League. \$27.50 net Cambridge South Asian Studies 31

\section{Peasants and Imperial Rule}

Agriculture and Agrarian Society in the Bombay Presidency, 1850-1935

\section{NEIL CHARLESWORTH}

This book examines the impact of British rule on the Indian peasantry. The author discusses such issues as the development of the British land revenue system, the pattern of expansion in commercial agriculture and the consequences in terms of ownership and organisation of land and agrarian social structure.

$\$ 30.00$ net

Cambridge South Asian Studies 32

\section{The Warrior Merchants}

Textiles, Trade, and Territory in South India

\section{MATTISON MINES}

This book presents a study of one of the most important artisan-merchant communities, the weavers, who form the second largest sector of the south Indian economy. It thus offers an important corrective to the unbalanced picture that we have of Indian social organisation from those accounts which have focused almost exclusively on agrarian society.

$£ 19.50$ net

\section{Cambridge University Press}

The Edinburgh Building, Shaftesbury Road, Cambridge CB2 2RU, England 
Agrarian Power and Agricultural Productivity in South Asia Edited by MEGHNAD DESAI, SUSANNE HOEBER RUDOLPH \& ASHOK RUDRA This collection of articles represents a radical departure in the methodology of understanding economic and political developments in new nations.

South Asia Political Economy Projects, Voltume 1

£23.75 Hardback 394pp 0-520-05369-9

Women in Buddhism: Images of the Feminine in the Mahāyāna Tradition DLANA Y. PAUL

This collection of Buddhist religious texts depicting the role of women is analysed to show the different attitudes taken by different groups of Buddhists towards women. $£ 28.50$ Hardback 350pp illus. 0-520-05445-8; $\$ 8.50$ Paperback 0-520-05428-8

Art of Nepal: A Catalogue of the Los Angeles County Museum of Art Collection PRATAPADITYA PAL

This unique catalogue raisonné covers sculptures, drawings from artists' model books and priests' manuals and paintings, each section having its own generous art historical introduction.

c.\$45.95 Hardback 300pp illus. 0-520-05406-7: c.\$20.75 Paperback 0-520-05407-5

\section{Now available in paperback:}

The Golden Peaches of Samarkand: A Study of Tang Exotics EDWARD SCHAFER

c. 11.95 Paperback 418pp illus. 0-520.05462-8

The Vermilion Bird: T'ang Images of the South

EDWARD SCHAFER

c.\$11.95 Paperback

392 pp illus. $0.520-05463-6$ 


\section{MODERN ASIAN STUDIES}




\section{Modern Asian Studies \\ Volume i 9 I 985}

EDITOR

Gordon Johnson

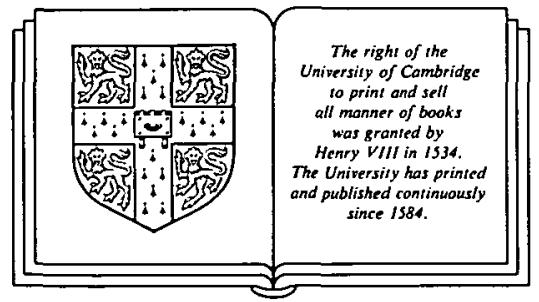

\section{GAMBRIDGE UNIVERSITY PRESS}

\section{CAMBRIDGE}

LONDON NEWYORK NEW ROCHELLE

MELBOURNE SYDNEY 
Published by the Press Syndicate of the University of Cambridge The Pitt Building, Trumpington Street, Cambridge CB2 IRP 32 East 57th Street, New York, NY 10022, USA io Stamford Road, Oakleigh, Melbourne 3166, Australia

(C) Cambridge University Press ig8

Modern Asian Studies is concerned with the history, geography, politics, sociology, literature, economics and social anthropology of South Asia, SouthEast Asia, China and Japan.

Contributions should be based on original research or field-work. They should be between 2000 and 8000 words long. Two typed copies should be submitted. Each author will receive twenty-five free offprints of his article and a copy of the Journal in which it appears.

Submission of an article will be taken to imply that it has not been previously published and that it is not on offer to any other publisher. In the interests of authors, copyright is normally assigned to Cambridge University Press. The editor welcomes expression of all shades of opinion, but responsibility for them rests with their authors.

All correspondence should be addressed to Dr Gordon Johnson, Selwyn College, Cambridge $\mathrm{CB}_{3}$ 9DQ, England. 
Barbara D. Metcalf: Nationalist Muslims in British India: the Case of Hakim Ajmal Khan

Ayesha Jalal: Inheriting the Raj: Jinnah and the GovernorGeneralship Issue

Michelle Maskiell: Social Change and Social Control: College-Educated Punjabi Women 1913 to 1960

Lucy Carroll: The Ithna Ashari Law of Intestate Succession: An Introduction to Shia Law Applicable in South Asia

Chew Huat Hock: Some Observations on Coalition Politics in Penang

Nguyen The Anh: The Vietnamese Monarchy under French Colonial Rule I $884^{-1} 945$

C. A. BAyly: The Pre-History of 'Cummunalism'? Religion, Conflict in India, I 700-186o

Lakshmi Subramanian: Capital and Crowd in a Declining Asian Port City: The Anglo-Bania Order and the Surat Riots of 1795

Michael H. Fisher: The Imperial Coronation of i 8 I 9: Awadh, the British and the Mughals

Peter H. Prindle: Peasant-worker Households and Community-based Organizations in Rural Japan

Roger Buckley: Joining the Club: the Japanese Question and Anglo-American Peace Diplomacy, 1950-I95 I

GORDON JOHNSON: Introduction

Irfan Habib: Studying a Colonial Economy-Without Perceiving Colonialism

Dharma Kumar: The Dangers of Manichaeism 
Ashin Das Gupta: Indian Merchants and the Western Indian Ocean: The Early Seventeenth Century

Amiya Kumar Bagchi: Transition from Indian to British Indian Systems of Money and Banking I 800-1850

Neil Charlesworth: The Problem of Government Finance in British India: Taxation, Borrowing and the Allocation of Resources in the Inter-War Period

Shri Prakash: Models of Peasant Differentiation and Aspects of Agrarian Economy in Colonial India

Crispin N. Bates: Regional Dependence and Rural Development in Central India: The Pivotal Role of Migrant Labour

Colin Simmons: 'De-industrialisation', Industrialisation and the Indian Economy. c. 1850-1947

Rajnarayan Chandavarkar: Industrialization in India before 1947: Conventional Approaches and Alternative Perspectives

B. R. Tom Linson: Writing History Sideways: Lessons for Indian Economic Historians from Meiji Japan

J. F. Richards, James R. Hagen and Edward S. Haynes: Changing Land Use in Bihar, Punjab and Haryana, I850-I $97^{\circ}$

Satish Chandra Mishra: Agricultural Trends in Bombay Presidency 1900-1920: The Illusion of Growth

David Gosuing: Thailand's Bare-headed Doctors

Simon Barraclough: The Dynamics of Coercion in the Malaysian Political Process

K. M. WELLS: The Rationale of Korean Economic Nationalism Under Japanese Colonial Rule, I 922-I 932: the Case of Cho Man-sik's Products Promotion Society 


\section{REVIEWS}

Karma: An Anthropological Inquiry, by Charles F. Keyes and Valentine Daniel (K. R. Norman)

Krishna, the Butter Thief, by John Stratron Hawley (K. R. Norman)

A Bibliography of Ceylon (Sri Lanka). A Systematic Guide to the Literature on the land, People, History and Culture published in Western Languages from the Sixteenth Century to the Present Day, by H. A. I. Goonetileke (B. H. Farmer)

Religion and Politics in Muslim Society: Order and Conflict in Pakistan, by Akbar S. Ahmed (Francis Robinson)

South Asian Archaeology 1981: Proceedings of the Sixth Conference of the Association of South Asian Archaeologists in Western Europe by Bridget Allchin (K. R. Norman)

Caste, Morality and Western Religion under the Raj. Caste and Christianity: Attitudes and Policies of Anglo-Saxon Protestant Missionaries in India, by Duncan B. Forrester; Catholic Missionaries in a British Colony: Successes and Failures in Ceylon, 1796-1893, by Robrecht Boudens; Race, Sex and Class under the Raj: Imperial Attidues and policies and their Critics, 1793-1905, by KENNETH Ballhatchet (R. E. Frykenberg)

From Empiricist Conflation to Distortion: Caste in South Asia (Michael Roberts)

Injurious to Public Morals: Writers and the Meiji State, by JAY RuBIN (Richard Bowring)

The Japanese Colonial Empire, 1895-1945, edited by Ramon H. Myers and Mark R. Peattie (A. R. Michell)

The Indianness of Rudyard Kipling: A Study in Stylistics, by S. S. Azfar Husain (M. Moizuddin)

Subject to Famine: Food Crises and Economic Change in Western India, 1860-1920, by Michelle Burge McAlpin (Crispin Bates) 
A New Face of Hinduism: The Swaminarayan Religion, by Raymond Brady Williams (Marcus Banks)

Sri Lanka in Change and Crisis, edited by James Manor (B. H. Farmer)

Southeast Asian Affairs 1984 (Lionel Carter)

Ahmad Bashir and the Majlis-i-Pakistan: A Correction (R. J. Moore) 876 


\section{(C) Cambridge University Press 1985}

\section{Copying}

This journal is registered with the Copyright Clearance Center, 2 I Congress St., Salem, Mass. or 970. Organizations in the USA who are also registered with CCC may therefore copy material (beyond the limits permitted by sections 107 and 108 of US Copyright law) subject to payment to CCC of the per-copy fee indicated in the code on the first page of the article. This consent does not extend to multiple copying for promotional or commercial purposes.

ISI Tear Service, 350 I Market Street, Philadelphia, Pennsylvania I 9 I 04 , USA, is authorised to supply single copies of separate articles for private use only.

For all other use, permission should be sought from the Cambridge or New York offices of the Cambridge University Press.

Claims for missing issues should be made immediately upon receipt of the subsequent issue.

Modern Asian Studies is concerned with the history, geography, politics, sociology, literature, economics and social anthropology of South Asia, South-East Asia, China and Japan.

Contributions should be based on original research or field-work. They should be between 2000 and 8000 words long. Two typed copies should be submitted. Each author will receive twenty-five free offprints of his article and a copy of the Journal in which it appears.

Submission of an article will be taken to imply that it has not been previously published and that it is not on offer to any other publisher. In the interests of authors, copyright is normally assigned to Cambridge University Press. The editor welcomes expression of all shades of opinion, but responsibility for them rests with their authors.

All correspondence should be addressed to Dr Gordon Johnson, Selwyn College, Cambridge $\mathrm{CB}_{3} 9 \mathrm{DQ}$ England.

CONTENTS OF VOLUME 20 PART I FEBRUARY I 986

(provisional)

Peter Carey: Waiting for the 'Just King': The Agrarian World of South-Central Java from Giyanti (1755) to the Java War (1825-30)

M. C. Ricklefs: Some Statistical Evidence on Javanese Social Economic and Demographic History in the Later Seventeenth and Eighteenth Centuries

Peter Boomgaard: Buitenzorg in 1805 : The Role of Money and Credit in a Colonial Frontier Society

R. E. Elson: Sugar Factory Workers and the Emergence of 'Free Labour' in Nineteenth-Century Java

B. H. Farmer: Perspectives on the 'Green Revolution' in South Asia

Peter Robr: The Challenge of Gau Mata: British Policy and Religious Change in India, I880- 1916 


\title{
MODERN ASIAN STUDIES
}

\author{
VOLUME I 9 PART 4 OCTOBER I 985
}

ARTICLES

PAGE

Satish Chandra Mishra: Agricultural Trends in Bombay Presidency i goo-i 920: The Illusion of Growth

David Gosting: Thailand's Bare-headed Doctors

761

Simon Barraclough: The Dynamics of Coercion in the Malaysian Political Process

K. M. Wells: The Rationale of Korean Economic Nationalism Under Japanese Colonial Rule, r 922-I932: The Case of Cho Man-sik's Products Promotion Society

Injurious to Public Morals: Writers and the Meiji State, by JAy Rubin (Richard Bowring)

The Japanese Colonial Empire, 1895-1945, edited by Ramon H. Myers and Mark R. Peattie (A. R. Michell)

The Indianness of Rudyard Kipling: A Study in Stylistics, by S. S. Azfar Husain (M. Moizuddin)

Subject to Famine: Food Crises and Economic Change in Western India, i860-1920, by Michelle Burge McAlpin (Crispin Bates)

A New Face of Hinduism: The Swaminarayan Religion, by Raymond Brady Williams (Marcus Banks)

Sri Lanka in Change and Crisis, edited by James Manor (B. H. Farmer)

Southeast Asian Affairs 1984 (Lionel Carter)

Ahmad Bashir and the Majlis-i-Pakistan: A Correction. R. J. Moore)

\author{
(C) Cambridge University Press 1985 \\ C.AMBRIDGE UNIVERSITY PRESS
}

The Pitt Building, Trumpington Street, Cambridge CB2 I RP 32 East 57 th Street, New York, NY 10022, USA

io Stamford Road, Oakleigh, Melbourne 3166, Australia 